\title{
Entre Exu e Ogum: políticas do sagrado no teatro de Abdias do Nascimento
}

\author{
Between Exu and Ogum: politics of the sacred \\ in the drama by Abdias do Nascimento \\ Entre Exu y Ogum: políticas del sagrado \\ en el teatro de Abdias do Nascimento
}

Rainério dos Santos Lima*

\section{Resumo}

Estudo crítico das determinantes míticas na caracterização das personagens e na composição da ação em Sortilégio II, drama de Abdias do Nascimento. O teatro de Abdias obedece a paradigmas de composição da cena que não se baseiam mais na organicidade sintagmática da fábula, mas, apresentando os complexos e paixões de Emanuel, busca uma organização descontínua e paradigmática, para dar conta da vida de uma única e dominante subjetividade em cena. Em Sortilégio II, essa configuração teatral pós-catástrofe é ideal para tecer os processos rememorativos de Emanuel, na tentativa de projetar no presente da cena o passado traumático do personagem, marcado pela violência social, pelos complexos raciais e pelas contraditórias relações eróticas com Ifigênia e Margarida. Na peça, além das definições estruturais da ação, o sagrado afro-brasileiro e a mitologia dos Orixás são importantes modulações culturais que interferem nas relações de poder entre os agentes e nos processos de subjetivação que acometem Emanuel. Uma rede social e simbólica que, sob a tutela de Exu e Ogum, concorre para a libertação e deificação do personagem. Por meio do reconhecimento da cultura negra, do pertencimento étnico-racial e do sacrifício mítico, Emanuel deixa o mundo racista dos homens para habitar o Orún, o plano divino dos Orixás.

Palavras-chave: drama, mitologia dos Orixás, Abdias do Nascimento.

\section{Abstract}

Critical study of mythic determinants in the construction of characters and composition of action in Sortilégio II ("Sortilege II"), drama by Abdias do Nascimento. The theater by Abdias obeys to paradigms of scene composition that go beyond the sintagmatic organicity of fable, but, in presenting the complexes and passions of Emanuel, it searches a discontinuous and paradigmatic organization in order to deal with the life of a unique and dominant subjectivity in scene. In Sortilégio II, this post-catastrophe theater configuration is ideal to weave the Emanuel's rememorative processes in the attempt to project the character traumatic past onto the present scene, marked by social violence, racial complexes and contradictory erotic relations with Ifigênia and Margarida. In the play, besides the structural definitions of action, the Afro-Brazilian sacred and the Orishas mythology are important cultural modulations that interfere in the relations of power among agents and in the processes of subjectivation that affect Emanuel. A social and symbolic network, under the tutelage

\section{Resumen}

Estudio crítico de los determinantes míticos en la caracterización de los personajes y en la composición de la acción en Sortilegio II, drama de Abdias do Nascimento. El teatro de Abdias obedece a paradigmas de composición de la escena que no se basan más en la organicidad sintagmática de la fábula, pero, presentando los complejos y pasiones de Emanuel, busca una organización discontinua y paradigmática, para dar cuenta de la vida de una única y dominante subjetividad en la escena. En Sortilegio II, esta configuración teatral post-catástrofe es ideal para tejer los procesos rememorativos de Emanuel, en el intento de proyectar en el presente de la escena el pasado traumático del personaje, marcado por la violencia social, por los complejos raciales y por las contradictorias relaciones eróticas con Ifigenia y Margarida. En la pieza, además de las definiciones estructurales de la acción, el sagrado afro-brasileño y la mitología de los Orixás son importantes modulaciones culturales que interfieren en las relaciones de poder entre los agentes y en los procesos de subjetivación que acomete Emanuel. Una red social y simbólica que, bajo la tutela de Exu

\footnotetext{
* Universidade Federal do Oeste do Pará (UFOPA), Santarém, PA, Brasil. Dorcid.org/0000-0002-6885-5342. E-mail: rainerio.lima@ufopa.edu.br
} 
of Eshu and Ogoun, contributes to the liberation and deification of the character. Through the recognition of black culture, of ethno-racial belonging, and mythical sacrifice, Emanuel leaves the human racist world to inhabit Orún, the divine plan of the Orishas.

Keywords: drama, Orixas mythology, Abdias do Nascimento. y Ogum, concurre para la liberación y la deificación del personaje. Por medio del reconocimiento de la cultura negra, de la pertenencia étnico-racial y del sacrificio mítico, Emanuel deja el mundo racista de los hombres para habitar el Orún, el plan divino de los Orixás.

Palabras-clave: drama, mitología de los Orixás, Abdias do Nascimento.

\begin{abstract}
Quando a filha-de-santo se deixa cavalgar pelo seu orixá, a ela se abre como palco o barracão em festa, para o que talvez seja a única possibilidade na sua pobre vida de experimentar uma apresentação solo, de estar no centro das atenções, quando seu orixá, paramentado com as melhores roupas e ferramentas de fantasia, há de ser admirado e aclamado por todos os presentes, quiçá invejado por muitos. E por toda a noite o cavalo dos deuses há de dançar, dançar e dançar. Ninguém jamais viu um orixá tão bonito quanto o seu.
\end{abstract}

Reginaldo Prandi

Meus personagens são deuses que se manifestam dançando.

Zora Seljam

\title{
Emanuel
}

Além de Sortilégio II: (mistério negro de Zumbi redivivo), Abdias do Nascimento escreveu apenas Rapsódia negra, em 1952, um roteiro de espetáculo no modelo do teatro de revista, com números dançados, cantados e musicados. Escrita para propor uma estética afro-brasileira, o texto de Sortilégio II teve duas versões oficiais. A primeira, de 1951, foi encenada em 1957 pelo Teatro Experimental do Negro (TEN), no Teatro Municipal do Rio de Janeiro, sob a direção de Leo Jusi, após uma longa batalha jurídica para ser liberada pela censura, sendo publicada apenas em 1961 na coletânea Dramas para negros, prólogo para brancos. A segunda saiu em 1979, quando o dramaturgo já havia migrado para os Estados Unidos e viajado por vários países africanos. O estudo crítico da segunda versão de Sortilégio II precisa considerar a estadia do dramaturgo em Ilê Ifé, na Nigéria, entre os anos de 1976 e 1977, viagem na qual teria se aprofundado no conhecimento das religiões dos Orixás (Nascimento, 2004, p. 220). A passagem pela cidade sagrada de Ilê-Ifé pode ser interpretada como estratégia pessoal de busca por fundamentos culturais que pudessem alicerçar a sua ação como militante político e melhor embasar os referenciais como artista e escritor. Segundo Abdias do Nascimento, a estrutura dramática entre as versões é a mesma, a diferença entre os dois textos estaria no acentuado tom político, no mergulho no universo religioso da última e no agenciamento da figura de Zumbi "na luta por libertação, dignidade humana e soberania dos povos negro-africanos" (Nascimento, 1978, p. 14).

Sortilégio II dramatiza a trajetória do advogado Emanuel e as relações conflituosas que este estabelece com Ifigênia, com Margarida, com os policiais, com a identidade negra e com a religião dos Orixás. O drama, organizado em apenas um ato, inicia com um "prólogo" efetuado pelas Filhas de Santo (Filhas I, II e III) e pela Yalorixá, a sacerdote chefe do templo religioso, em que são definidas algumas linhas de estruturação da peça: as quatro personagens falam sobre os perigos de se negar a cultura religiosa de origem, são antecipados os segredos que envolvem as relações amorosas de Emanuel com Ifigênia e com Margarida e é enunciada a profecia de que uma grande transformação espiritual estaria para acontecer naquela noite. Em meio as ocupações rituais que antecipam as festas públicas no terreiro, as Filhas de Santo enxergam e anunciam a chegada de Emanuel, que subia o morro fugindo da polícia após assassinar Margarida. Ao chegar no caminho que dá acesso ao terreiro, Emanuel entra no espaço sagrado para se esconder e, assim, dá-se início à ação propriamente dita. 
As ações do drama oscilam entre dois polos de representação teatral, motivados ora pela memória de Emanuel, ora pela interferência mítica das forças sagradas do Candomblé. Após Emanuel chegar no terreiro e cair cansado próximo à gameleira sagrada e aos pés do despacho de Exu, a memória do personagem projeta fragmentos de sua vida em cena, que aparecem em forma de espectros, imagens e figuras fantasmagóricas de um passado marcado pelo preconceito racial. Esses fragmentos de vida são agenciados do passado para o presente como projeção da mente de Emanuel, nos diálogos tensivos com os espectros de Margarida e Ifigênia e com as Filhas de Santos I, II e III, as quais, muitas vezes, funcionam como dispositivos que acionam a memória do personagem, transferindo para o palco os episódios que precisam ser problematizados. O que é objetivado na cena não é o presente dos personagens em continuum, como no drama burguês, mas episódios do sombrio passado de Emanuel. Da infância na escola ao casamento e morte de Margarida, os fragmentos de vida são revistos por uma subjetividade masculina que avalia digressivamente suas paixões de forma injusta e cruel. Logo, a ação dramática de Sortilégio II não segue a organicidade e a sequência sintagmática do teatro aristotélico-hegeliano; ao contrário, é estruturada paradigmaticamente através da justaposição descontínua dos quadros. O drama, dessa forma, não mostra a progressão dos conflitos entre subjetividades de objetivos opostos, até o momento de crise e a consequente catástrofe. De modo diferente, consumada a catástrofe - o assassinato da esposa pelo marido ciumento -, o teatro narra a vida de um único sujeito de trás para a frente, objetivando seus traumas, crimes e paixões que, por sua vez, retornam ciclicamente em um tipo de prestações de contas.

É por isso que, na peça de Abdias do Nascimento, as outras figuras dramáticas se apresentam "como imagens fantasmáticas, significantes que se alinham na sintaxe enunciativa do texto, espelhos onde o protagonista se vê" (Martins, 1995, p. 110). A própria noção de personagem se desestabiliza, pois figuras como Margarida e Ifigênia, por exemplo, são projeções da mente do "eu" organizador da fábula, como no drama expressionista (Bornheim, 1992, p. 36). Além disso, obedecendo à essa subjetividade dominante, muitas reminiscências são articuladas apenas através do uso da voz em off, como são os casos da Voz de negra velha, da Voz da mãe da Margarida, das Vozes agressivas dos policiais, do Delegado e das Vozes infantis.

Certamente, as estratégias teatrais adotadas pelo dramaturgo têm a ver com os contatos intelectuais estabelecidos com Nelson Rodrigues e Eugene O'Neill. Na dramaturgia brasileira, antes de Sortilégio II, apenas Vestido de noiva de Nelson Rodrigues e A moratória de Jorge Andrade trataram artisticamente da memória pessoal dos personagens como potencial elemento configurativo do texto teatral. Vestido de noiva é de 1943 e A moratória foi encenada em 1955, apenas dois anos antes da primeira versão de Sortilégio II subir ao palco do Teatro Municipal do Rio de Janeiro, em 1957 (Nascimento, 2004, p. 219). Em especial, Nelson Rodrigues estabelecia uma considerável relação com o Teatro Experimental do Negro (TEN). Ainda que a primeira montagem de Anjo negro (escrita em 1946), de Nelson Rodrigues, tenha ocorrido em 1948 no Teatro Fênix, pela companhia Teatro Popular de Arte (TPA) de Sandro Polloni e Maria Della Costa, com direção de Ziembinski e não pelo TEN, Abdias do Nascimento o inclui entre os textos teatrais de Dramas para negros, prólogo para brancos (Nascimento, 1961, p. 310). Soma-se a isso o fato de haver muitas aproximações na organização da fábula de Sortilégio II e de Vestido de noiva (Rodrigues, 2010). Enquanto neste, a ação se divide entre plano da realidade, plano da alucinação e plano da memória da personagem Alaíde; naquele, a ação oscila entre os fragmentos da memória de Emanuel e as situações de fundo mítico, provocadas pela interferência de Exu e Ogum.

Quanto à Eugene $\mathrm{O}^{\prime}$ Neill, as trocas artísticas também são evidentes. Abdias do Nascimento afirma que a ideia de criar o Teatro Experimental do Negro lhe ocorreu quando assistiu uma montagem de Imperador Jones, de Eugene O'Neill, no Teatro Municipal de Lima, no Peru, em 1941 (Nascimento, 2004, p. 209). Imperador Jones, por sinal, foi o primeiro espetáculo montado profissionalmente pelo Teatro Experimental do Negro, em 1945, com a autorização de Eugene O'Neill, com quem Abdias do Nascimento mantinha correspondência (Nascimento, 1978, p. 31). Considerando que, para a montagem de Imperador Jones, os integrantes do TEN certamente se debruçaram sobre a produção dramática de Eugene O'Neill, não é absurdo supor que os 
procedimentos estéticos utilizados pelo autor de Estranho Interlúdio para representar subjetividades transtornadas podem ter contaminado a dramaturgia de Abdias do Nascimento.

\section{Tempo-Templo}

De forma descontínua e episódica, toda a vida de Emanuel é rememorada pelo personagem no intervalo cronológico de apenas uma hora, entre as onze e as doze horas da noite. Horário significativo, pois nos intervalos temporais de passagem de turno haveria uma conjuntura sobrenatural que propiciaria um contexto de intercomunicação entre a realidade mundana e $\mathrm{o}$ plano sagrado das divindades afro-brasileiras. No drama de Abdias do Nascimento, a meianoite é o horário no qual Exu baixa nos terreiros, logo após os Encantados e as outras divindades do Candomblé deixarem os filhos e filhas que estavam em transe. Contraposta a esse tempo cronológico, a temporalidade interna do drama é, concomitantemente, subjetiva e mítica. Embora a ação se passe entre as onze e as doze horas da noite, os episódios e os quadros são o resultado da subjetividade de Emanuel e do conflito entre essa subjetividade e as potências míticas dos Orixás. Não havendo coincidência entre o tempo cronológico e o tempo mítico-subjetivo, a temporalidade da peça é regida tanto pela mente do personagem, quanto pelo desígnio mítico necessário para moldar a transformação existencial de Emanuel em ser político e sagrado.

As marcações espaciais também obedecem a fundamentos sagrados, legítimos e ideais para a manifestação dos deuses Orixás. Estando o palco delimitado, na direita, pela pedra de sacrifício (altar) de Ogum, pelo pegi de Exu (pequena e rústica capela) e, na fronteira esquerda, pela árvore sagrada, a gameleira branca (Nascimento, 1979, p. 41), pode-se dizer que o espaço no qual se passa a ação está pontuado por símbolos religiosos que criam um espaço modelar para a manifestação do sagrado afro-brasileiro na vida de Emanuel. Ogum, da pedra de sacrifício, é considerado o Orixá dos ferros, da metalurgia e das armas, regendo desde as grandes batalhas mundiais até a luta diária pela sobrevivência do ser humano. Ogum é o arquétipo do guerreiro, do general que luta na frente do campo de batalha, desbravando e enfrentando o desconhecido, fomentando as vitórias da vida. Ogum "é dono dos caminhos, da tecnologia e das oportunidades de realização pessoal" (Prandi, 2001, p. 21). Possuidor de forças ambivalentes, Ogum é a representação divina das potências de criação e destruição presentes nos instrumentos compostos de ferro, nas ferramentas e nas armas criadas pela humanidade: "Ogum é aquele que protege e mata", "O fundador e o destruidor de cidades" (Risério, 1996, p. 74).

Já Exu, divindade mensageira dos Orixás, é o patrono dos caminhos, das portas, das passagens e das encruzilhadas. Sem Exu, "os orixás e humanos não podem se comunicar [...] sem sua participação não existe movimento, mudança ou reprodução, nem trocas mercantis, nem fecundação biológica" (Prandi, 2001, p. 20-21). Princípio ativo e dinâmico, Exu, entre outros atributos, é "o responsável pela circulação do axé que dinamiza o ciclo vital" (Luz, 2000, p. 50), é Orixá que promove "a dinamização e expansão do universo, sendo o responsável pela ação de introjeção e restituição de axé" (Luz, 2000, p. 51). Considerados irmãos, Exu e Ogum são Orixás que aparecem distribuídos espacialmente no palco junto com a gameleira branca. Árvore sagrada de copa frondosa, a gameleira é onde reside Iroco, o Orixá do tempo. Em sua representação simbólica, a gameleira é a planta primordial que, na rede de mitos que rege as religiões afro-brasileiras, foi a árvore primeira que esteve no início dos tempos quando o mundo foi criado e organizado. Iroco faz parte do processo de criação do cosmo e em torno da qual as coisas e os seres tomaram forma e corpo, sua representação está associada à própria busca de compreensão do sentido da vida.

Assim, o território pisado por Emanuel ao subir o morro fugindo da polícia é, por fundamento mítico ancestral, um território do sagrado, possuidor de axé. É no cruzamento dos caminhos que levam ao terreiro ou à cidade que Emanuel encontra o refúgio necessário para escapar da perseguição dos agentes. Em outras palavras, Emanuel é forçado a permanecer em um "espaço sincrético que representa, ainda, a encruzilhada de sua própria existência" (Martins, 1995, p. 108). A topografia proposta no drama ainda caracteriza o alto do morro como lugar sagrado, protegido 
pelos deuses africanos, enquanto que a cidade, em plano baixo, vista em panorâmica da borda da ribanceira, é o lugar onde a população negra encontra injustiça e humilhação: "Negro desce toda manhã... Faz força de sol a sol: quebrando pedra... tirando lixo das ruas... carregando peso no cais do porto. É só o que lhe permitem fazer" (Nascimento, 1979, p. 77).

É no espaço sagrado do terreiro, entre a gameleira sagrada, o pegi de Exu e a pedra-altar de Ogum que Emanuel redescobrirá os dispositivos de identificação da cultura negra por ele renegada. A entrada de Emanuel no espaço sagrado também marca uma espécie de ruptura no espaço-tempo. A partir daquele momento seu corpo, suas falas e seus pensamentos estão submetidos à temporalidade interna do terreiro, templo sagrado que obedece ao tempo cíclico inaugurado pelos Orixás. Daí talvez a necessidade da gameleira branca, representativa da temporalidade própria da liturgia do Candomblé. O espaço habitado por Emanuel passa a ser o ambiente que segue a temporalidade representada por Iroco, a planta-deus que estava no começo da criação quando o caos foi organizado em ordem. Ao fugir, Emanuel cruza a fronteira que separa o mundano do território sagrado. Feito isso, Emanuel também penetra no lugar que provocará a crise da sua subjetividade, forçando o personagem a enfrentar as imagens fantasmagóricas e espectrais do passado problemático, crise necessária para a sua dinâmica subjetivação.

$\mathrm{Na}$ verdade, a transformação existencial pela qual passará Emanuel já se encontra antecipada no início do drama, nos diálogos entre as Filhas de Santo I, II e III e a Yalorixá. Na consulta ao oráculo de Ifá, o Orixá que rege a comunicação entre o plano terreno e o universo divino, as quatro participam da cena que revela o odu que profetiza a dolorosa transformação de Emanuel. No extenso emaranhado de mitos cantados por Ifá, o colar sagrado (opelê) revela a combinação de sementes que remete ao $o d u$ da transformação, da morte e da ressurreição. Nas enigmáticas falas da Yalorixá: "Será uma longa jornada dentro do sangue... um mergulho na profundeza das menstruações" (Nascimento, 1979, p. 46); "Parece que ainda há mais... Sim, os Eguns... também estarão presentes... Vão dançar o festival da passagem..." (Nascimento, 1979, p. 47). Exu acompanha todo o processo de profecia e conversão, pois, além de princípio dinâmico que dá mobilidade ao cosmo, ele é o Orixá que conhece a linguagem dos deuses e todas as línguas humanas, possibilitando que as palavras sagradas de Ifá sejam traduzidas e compreensíveis aos ouvidos dos devotos.

Tal sequência dramática delineia um quadro mítico no qual a trajetória de Emanuel parece estar definida pelos deuses desde o assassinato de Margarida. É como se Emanuel encontrasse o terreiro no alto do morro atraído pela força de Exu, o senhor que comanda e abre os caminhos: "FILHA II - Exu faz o tempo e o espaço. Ele agora está criando os próximos momentos de Emanuel..." (Nascimento, 1979, p. 54). Claro que as previsões de Ifá se concretizarão, mas é Exu a divindade que tece os trajetos que Emanuel seguirá para sair da situação extrema na qual se encontra. Além disso, do mesmo modo que nas festas públicas, Exu recebe as primeiras oferendas para possibilitar o sucesso dos rituais e a comunicação dos deuses com os seus sacerdotes e devotos. O drama inicia com um despacho que sacrifica um galo para Exu. Tal oferenda não deixa de ser uma projeção do futuro sacrifício de Emanuel no final da peça, sacrifício místico que o lançará para a região encantada, para a morada das divindades.

\section{Mito e subjetivação}

Tendo nome bíblico, "Deus conosco", advogado e de origem pobre, Emanuel é esculpido como um personagem negro que sobrevive em uma organização social adversa, racista e violenta. O modo como Emanuel é interpelado nos diferentes contextos sociais definem-no como um sujeito humano que não consegue escapar à violência e aos complexos do racismo, processo que se infiltra nas instituições estatais e que se concretiza nas situações intersubjetivas. Obedecendo a esse ordenamento social, os episódios rememorados por Emanuel estão manchados por relações sociais degradadas que o identificam a imagens distantes do sentido de humanidade. Quando criança, um grupo de colegas da escola apelidava-o de "Tição", escorraçava-o e espancava-o. Quando jovem, foi preso muitas vezes e obrigado a cumprir penas por crimes que não teria cometido: “EMANUEL -- Desta vez não me pegam. Não sou mais 
aquele estudante idiota que vocês meteram no carro forte. Aos bofetões. Preso por quê? Ah! O carro não podia regressar vazio à delegacia" (Nascimento, 1979, p. 56-57). Adulto e graduado em Direito, formação historicamente associada à sociedade liberal, à autonomia do sujeito e à ascensão social, Emanuel ainda não consegue transcender os determinismos sociais de uma sociedade que o julga a partir de um lugar etnocêntrico. Embora tenha conseguido formação acadêmica em nível superior, atributo importante para conseguir respeitabilidade social, o personagem é impedido de se agenciar enquanto sujeito capaz de viver com dignidade.

Quando Emanuel acompanha Ifigênia ao distrito policial para denunciar o estupro sofrido pela garota, o Delegado, além de insultar a vítima, agride Emanuel que tentava defendê-la. O próprio Delegado, como resposta à reação violenta do namorado de Ifigênia, pega e rasga sua carteira profissional, joga-o na prisão e ordena: "Metam o doutor africano no xadrez!" (Nascimento, 1979, p. 95). Em outra situação, visto com Margarida quando retornava de uma festa, Emanuel é rapidamente confundido com um meliante, sob a acusação que estaria roubando ou violentando a própria noiva e, por isso, é humilhado, espancado e preso.

Na mente conturbada de Emanuel, só haveria duas possibilidades de atitude para as pessoas vítimas dessa dominação. Ou elas se reduziriam ao conformismo de sobreviver em uma sociedade dominada pelo preconceito racial, tentando a todo custo continuar invisíveis, relegando-se a lugares subalternos, ou elas reagiriam violentamente, forçadas que seriam a lutar ferozmente pela autonomia: "O negro desce o morro, mas... sabe lá se volta? Quando não é preso lá embaixo como marginal, perseguem o desgraçado até cá em cima. Quem não vira valente? Branco ou preto? E se defende? A pau... à bala... ou à faca?" ((Nascimento, 1979, p. 78).

Em Sortilégio II, as relações étnicas entre os personagens brancos e negros se fazem ou pela violência ou pelo impulso sexual-erótico, o qual, muitas vezes, se revela com consequências tão degradantes quanto a primeira. $\mathrm{O}$ desejo de Emanuel por mulheres brancas e a caracterização dramática de Ifigênia encaixam-se nessa opção. Embora possua o nome da Santa Católica de origem etíope, Ifigênia está sob as influências sagradas de Oyá-Iansã e de Pomba Gira, divindades femininas afro-brasileiras. Talvez, por isso, Ifigênia oscile entre a representação da eterna namorada cujo amor não pôde se concretizar e a da mulher sexualmente transgressora que circula com desenvoltura nas zonas proibidas do prazer e do vício. Espaços moralmente proibidos para as mulheres, mas hipocritamente aceitos quando se trata da representação masculina.

Na memória de Emanuel, a vida de Ifigênia demonstra que, mesmo nos casos em que as relações entre pessoas brancas e negras se realizam pelo desejo sexual, estas relações se fazem mediadas pelos jogos de interesse daqueles que dominam os espaços de poder na sociedade. Ifigênia, tão vítima da engrenagem social etnocêntrica quanto Emanuel, logo entende que as leis do Estado são manipuladas a partir dos grupos sociais e étnicos que detém o poder institucional. É a partir desse triste entendimento que a jovem negra compreendeu que o estupro de que foi vítima não receberia o mesmo desprezo por parte do Delegado caso ela não fosse negra e pobre. Diz Ifigênia: "Amargura?... Sim, é verdade. A eterna amargura da cor. Naquele instante compreendi que a lei não está ao lado da virgindade negra..." (Nascimento, 1979, p. 95).

Ifigênia, ciente de que vive em um ambiente fechado de difícil mobilidade social, também julga que as possibilidades de ascensão artística como bailarina não estariam acessíveis a pessoas negras, condenadas que estariam a péssimas condições de vida, de saúde e de educação. Para ela, como o poder e os privilégios sociais estariam nas mãos das pessoas brancas, seria apenas por meio delas que poderia crescer socialmente e ser reconhecida como artista, "Que rapaz de cor poderia me oferecer a festa que me oferecem esta noite? [...]. Eles vão só me levar a uma boate... Não precisa se zangar [...]. Você não me diz nada? Faz parte da minha carreira, querido" (Nascimento, 1979, p. 98). Em um longo diálogo, a partir da perspectiva capciosa de Emanuel (não custa lembrar!), Ifigênia é confrontada sobre suas escolhas eróticas. A moça prontamente explica a Emanuel que, não sendo respeitada pelos homens brancos como mulher e como ser humano, teria se utilizado da única ferramenta que possuiria para tentar alcançar as chances de ascensão social, o próprio corpo, visto pelos homens sempre de forma erotizada, "Usei meu corpo como se usa uma chave" (Nascimento, 1979, p. 99). Em outro importante trecho, "A única coisa que interessava era... meu corpo! Fiz 
dele a minha arma, já que até você se ausentou. Gastava todo o seu tempo tentando conquistar suas brancas" (Nascimento, 1979, p. 99).

$\mathrm{Na}$ intenção de ajudar Ifigênia, Emanuel aconselha a bailarina para que fique longe do samba do morro, da gafieira e das rodas dos terreiros de Candomblé. Mas é exatamente por seguir os conselhos do namorado que Ifigênia se aproximará dos homens que a explorarão sexualmente. Após perder a virgindade, violentada por José Roberto, Ifigênia sai com outros homens e acaba caindo na prostituição. Nas recordações de Emanuel, a trajetória de Ifigênia obedece a um frágil princípio moral que finda por penalizá-la: ao preterir os negros em preferência aos homens brancos, Ifigênia é condenada à prostituição na Lapa. Na visão do personagem masculino, ao invés de ascensão social, a personagem encontraria um tipo de sanção divina que a faria entrar no meretrício, "Parecia cumprir uma ordem divina... Igual sacerdotisa executando um ato litúrgico... (vulgar) Por isso deixei Copacabana... me transferi para a Lapa..." (Nascimento, 1979, p. 99). No entanto, talvez seja importante destacar que, ao contrário do que projeta a mente de Emanuel, a relação de Ifigênia com uma sexualidade transgressora extrapola a causalidade moral apresentada, visto que a personagem se entregaria a outros homens como quem cumpre um "dever ritual", como bem afirma a Filha de Santo III (Nascimento, 1979, p. 51). Por isso, a imagem espectral de Ifigênia confronta Emanuel dizendo que manteria relações com outras pessoas como quem cumpre um desígnio superior, ou melhor, como uma sacerdotisa em pleno ritual sagrado. Um forte vínculo da sexualidade feminina com o sagrado que, notoriamente, é incompreensível à mentalidade do advogado, afeito à aspiração de pertencer a mesma sociedade que o marginaliza e violenta.

Diferente de Ifigênia, Margarida obedece a outros parâmetros de caracterização. Filha de fazendeiro, neta de um antigo senhor de engenho, branca e loura, Margarida sempre se interessou pelos rituais afro-brasileiros (apesar de também receber nome de Santa Católica). Tendo cumprido obrigações para Iemanjá, Orixá rainha do mar e da fertilidade feminina, Margarida é representada no drama como sendo o grande objeto de desejo de Emanuel, desejo que, realizado e consumado, será fundamental para a catástrofe que o abaterá. A proteção de Margarida por Iemanjá ou pela sereia Dona Janaína é essencial para compreendermos a representação da personagem. A importância dramática dessa proteção é demonstrada logo nas primeiras evocações do espectro de Margarida pela mente de Emanuel. Margarida entra vestida de noiva, acompanhada por cânticos à Iemanjá e pelo conjunto cênico da Teoria das Yaôs que, em ritmo de ondas do mar e utilizando uma rede de pesca (que é o "próprio véu de noiva"), trazem-na até Emanuel. Margarida é evocada sob a tutela das redes sedutoras de Odoyá, em entrada ritual que enfatiza "os gestos da mulher vaidosa" (Nascimento, 1979, p. 78). É evidente que, sendo projeção da mente de Emanuel, a apresentação de Margarida como sereia sedutora pronta para o matrimônio é também sintoma dos complexos raciais do advogado que deseja desposar as mulheres brancas e abandona Ifigênia à prostituição. Nas queixas da bailarina, o amante "vivia enrabichado pela branca. Uma verdadeira obsessão. Só falava em branca... branca... branca..." (Nascimento, 1979, p. 107).

O complexo e contraditório desejo sexual interétnico é o principal fio condutor das figurações da morte e da catástrofe presentes nos diferentes episódios rememorados por Emanuel, inclusive nas suspeitas de filicídio que recaem sobre Margarida, "Mãe branca que assassina o próprio filho negro" (Nascimento, 1979, p. 116). Tais figurações são ardilosamente sustentadas através de imagens associativas que aproximam semanticamente os pares lírio/casamento e cor branca/morte. Associações que, nas projeções mentais de Emanuel, iniciam-se na lembrança do casamento com Margarida e estarão pontuadas em vários momentos da ação dramática. Temos alguns exemplos: a) No casamento, a cor de Margarida, o branco do vestido de noiva e do buquê de lírios são prenúncios das desgraças vindouras: "FILHA III - Carne leitosa... branca como lírio... [...] / FILHA III (Dirigindo-se às Filhas I e II) Vergonha! Tirem depressa essa cara branca da morte. (ambas tiram)" (Nascimento, 1979, p. 6465); b) Na infância, apedrejado pelos colegas na escola, o sangramento na cabeça de Emanuel é associado a uma flor branca: "FILHA I - Longo lírio de haste ferida... escorrendo um mar de sangue!... / FILHA III - Maldição! / EMANUEL (Deprimido) - Tanto sangue! Como de uma 
pessoa varada ao meio por um punhal..." (Nascimento, 1979, p. 69); c) Em delírio, após discutir com o espectro de Ifigênia, beber e fumar o charuto de Exu, Emanuel vislumbra um buquê manchado de vermelho: "(Emanuel bebe. O Orixá atravessa a cena com o buquê de lírios, agora ensanguentados. [...]). EMANUEL - Que negócio será este?! Uma flor... lírios, quem sabe... [...] Toda vez que vejo lírio sinto cheiro de velório... mesmo lírio de casamento..." (Nascimento, 1979, p. 100); e d) Com Ifigênia, instantes antes de Emanuel reconhecer a responsabilidade pelo assassinato de Margarida: “EMANUEL - [...] Me ajude, Ifigênia! Me ajude! (observa o rosto dela, vê o buquê de lírios) Como é gentil... lírios para mim? [...] Mas... este lírio... parece o lírio do meu casa... Onde arranjou este buquê? Responda" (Nascimento, 1979, p. 118-119).

Em verdade, possuindo nome de flor, Margarida é a figura dramática que absorve todo o fúnebre leque semântico em torno do lírio branco e da morte. No intuito de ser aceito entre os círculos sociais que detém o poder, Emanuel desposa a desonrada filha de um antigo senhor de engenho. Mas o casamento com Margarida não será a sua salvação social, ao contrário, ao desposar uma mulher vítima da sociedade patriarcal, Emanuel dá passos para se tornar criminoso e assassino. O episódio do casamento de Emanuel, a praga pronunciada pela mãe de Margarida, o buquê de lírios brancos, enfim, tudo funciona ficcionalmente como antecipação do aborto do filho do casal ("criança não-nascida") e como profecia do assassinato de Margarida. Margarida, semelhante à Desdêmona no Otelo de Shakespeare, morre no leito nupcial pelas mãos de Emanuel, concretizando o sentido das associações semânticas internas ao drama. Ainda que a capciosa carta escrita por Ifigênia deflagre definitivamente a ira do advogado contra a esposa adúltera, é a cor branca que, como índice da violência étnico-racial e como dispositivo mítico-divino, assombra a mente do personagem desde a infância.

\section{Sacrilégio-Sacrifício}

Emanuel nega as manifestações da cultura negra como o samba e as danças sagradas do Candomblé. Os rituais afro-brasileiros são julgados por ele como cultos fetichistas, animistas, crenças religiosas de indivíduos iletrados, ocupação de pessoas de mentalidade selvagem que ainda viveriam em completo atraso moral e intelectual: "É por isso que essa negrada não vai para a frente... Tantos séculos no meio da civilização e o que adiantou? Ainda acreditando em feitiçaria... praticando macumba... culto animista!" (Nascimento, 1979, p. 58); e ainda, "Imaginem... eu tô falando como se também acreditasse nessas bobagens... Eu, o doutor Emanuel, negro formado... que aprendeu o catecismo... e em criança fez a primeira comunhão!" (Nascimento, 1979, p. 61). Ao ouvir Margarida evocar Iemanjá, Emanuel desacredita a fé da esposa: "Tão branca e ainda acredita em superstição de negro" (Nascimento, 1979, p. 84). Em outra situação, considerando o seu grau acadêmico, Emanuel chega a questionar a adesão a qualquer forma de crença religiosa como sendo atitude de pessoas incultas: "Até onde você foi parar, hein, Dr. Emanuel? Se apavorando à toa como um reles ignorante... Que adiantaram os anos de universidade?" (Nascimento, 1979, p. 104). Ainda que busque a fé Católica (aprendida com a mãe na infância) como oposição ao ritual do Candomblé que se desenrola nos bastidores das cenas, Emanuel age de modo prepotente em relações aos rituais afro-brasileiros e as crenças religiosas. Emanuel justifica seu comportamento por ser um homem que adquiriu um saber aceito oficialmente como ciência, um conhecimento associado à modernidade, ao progresso intelectual e à civilização ocidental.

A descrença e o cinismo de Emanuel motivam o personagem a assumir comportamentos agressivos e, até mesmo, profanadores para com os cultos aos Orixás. Refugiando-se dos policiais no terreiro, em um território sagrado, entre Exu, Ogum e Iroco, Emanuel ultrapassa o limite da prudência e do sacrilégio ao desafiar a força mítica e mística de Exu, o Orixá da mobilidade e da transformação: "Quero ver se o demônio dos negros é pior que o demônio dos brancos. (bebe: pausa esperando acontecer algo: depois, zombeteiro) Como é, Exu? Não acontece nada? (rindo) Não vai me transformar num sapo ou numa cobra?" (Nascimento, 1979, p. 67). E mais: "Bom marafo... charutos... comida no dendê... e dizem que até mulher nova ele gosta 
também. Quem não gosta? [...]. Pois não é que Exu gosta também de incenso? Deixa eu sentir o cheiro do perfume do diabo" (Nascimento, 1979, p. 69).

Ironicamente, a soberba de Emanuel em relação aos cultos afro-brasileiros aos poucos vai sucumbindo na medida em que o advogado se deixa influenciar pelos elementos rituais ao seu redor e, progressivamente, confronta os complexos psicológicos provocados pelo preconceito racial. Em vários momentos, na ânsia de desacreditar a energia divina de Exu e o culto as divindades afro-brasileiras, Emanuel consome imprudentemente os ingredientes que compõem o despacho. A sequência em que acontecem esses pequenos gestos é paralela à transformação espiritual do personagem em primeiro plano. A ordem dos gestos é a seguinte: $1^{\circ}$ ) Emanuel toca o ebó; $2^{\circ}$ ) depois toma a cachaça de Exu; $3^{\circ}$ ) acende e sente a fumaça do incenso; $4^{\circ}$ ) Emanuel pega a espada de Ogum para espantar o espectro de Ifigênia; $5^{\circ}$ ) o Orixá Ogum coloca um colar no pescoço do advogado que dança em transe; $6^{\circ}$ ) Emanuel bebe e fuma novamente o charuto de Exu; $7^{\circ}$ ) o personagem mais uma vez empunha a espada de Ogum contra policiais invisíveis; $8^{\circ}$ ) em seguida, bebe até se embriagar, fuma várias vezes o charuto e, transtornado, entra no pegi clamando pela manifestação do Orixá; $9^{\circ}$ ) acende velas ao lado da imagem da entidade e, de joelhos, reverencia e pede: “Meu Exu Odará... me salva!" (Nascimento, 1979, p. 105).

Assim, ao agir preconceituosamente contra os Orixás, cometendo sacrilégios contra Exu, Emanuel ingere e consome os ingredientes do ebó, além de tocar os objetos sagrados dos altares. Por meio do toque, da ingestão e da inalação material dos elementos rituais, Emanuel se contamina pelo axé contido neles e nos objetos sacros que ele tanto odiava. De maneira que, absorvendo o axé do templo, também assume comportamentos característicos de um indivíduo instável e perigoso. Transformação perceptível no nível discursivo onde parecem habitar dois seres que se interpelam provocativamente: "Mamãe... Emanuel... Deus conosco... Comigo? ... Mamãe... (reage) Deixa a pobre mãe sossegada... Tome mais um trago para levantar o moral... Outro charuto... (cínico) E se aparecer uma boa garota... ferro nela..." (Nascimento, 1979, p. 104).

Enquanto se deixa contaminar pelo sagrado afro-brasileiro, Emanuel despe as roupas que socialmente o identificavam como advogado e como sujeito de pretensões burguesas. No final, quando Emanuel já assumiu a culpa pelo assassinato de Margarida, o personagem emenda os fragmentos da memória, supera os complexos que o assombravam e, se agenciando como homem negro, rompe com o conformismo social. Com essa atitude, testemunha a necessidade de libertação definitiva do indivíduo de todos os mecanismos subjetivos e institucionais que ainda o sujeitam à discriminação étnico-racial: "Me roubaram tudo. [...] Agora me libertei. Para sempre. Sou um negro liberto da bondade. Liberto do medo, liberto da caridade e da compaixão de vocês. Levem também esses molambos civilizados, brancos" (Nascimento, 1979, p. 121).

Embora liberto dos complexos psicológicos que o escravizavam, a transformação de Emanuel só se completa no terreno do mito. Quando finalmente soam as doze badaladas da meia-noite, Exu se faz presente para receber as oferendas e os sacrifícios. O Ponto de Exu introduz a chegada do Senhor das Encruzilhadas. O Orixá se manifesta levando o revoltado Emanuel ao seu pegi, para concluir a transformação do agente. Lá, como em um casulo, Exu dinamiza as forças necessárias para efetuar a transformação mítica de Emanuel em um novo ser: "Igual à borboleta que abandona o casulo pra poder voar... Emanuel deixará a casca do ser que não é o seu próprio ser" (Nascimento, 1979, p. 66). Antecipado apenas pelos dançarinos que formam a Teoria dos Omolus - o Orixá da morte, das doenças, mas também da vida renascida -, Emanuel é transfigurado em novo indivíduo, um sujeito mítico, divino, pertencente ao sagrado afro-brasileiro. Representando um útero mítico, o pegi de Exu modifica ontologicamente o antigo Emanuel que, de negro conformado à violência do preconceito, renascerá como homem revoltado contra as estruturas racistas da sociedade, filho que é de Ogum, o Orixá das armas e da guerra: "Eu matei Margarida. Sou um negro livre" (Nascimento, 1979, p. 135).

Forças elementares primordiais são convocadas pela Yalorixá e pelas Filhas de Santo para agirem no corpo e na mente de Emanuel. O ritual da morte e ressurreição do advogado convoca várias divindades afro-brasileiras para apoiar e saudar a deificação do personagem. Por fim, Emanuel, paramentado com as roupas de Ogum, sai do pegi de Exu e, em seguida, é sacrificado no altar de seu Orixá protetor. De modo circular, o drama termina como começou, com o 
sacrifício para Exu. Encerrando o rito sacrificial aberto pela Yalorixá e Filhas de Santo, Emanuel morre para o mundo histórico e profano, mas, como Zumbi dos Palmares, renasce no tempo mítico-sagrado e se eterniza na memória coletiva, junto aos seus ancestrais. Pelo sacrifício, Emanuel é apartado da esfera e do acesso humano e, consagrado aos Orixás, passa a pertencer à uma realidade puramente divina (Agamben, 2007, p. 65). Emanuel morre de braços abertos como quem alça voo, ou como quem oferece o próprio sangue para alimentar as potências que movem o cosmo sagrado. $O$ grande e esperado sacrifício da noite se completa, o sangue de Emanuel fará parte da corrente de axé que move o mundo. A morte e o renascimento mítico reforçam o poder divino dos Orixás entre os humanos e fortalecem os elos de intercomunicação entre o Ayê e o Orún.

\section{Referências}

AGAMBEN, Giorgio (2007). Profanações. Tradução de Selvino José Assman. São Paulo: Boitempo.

BASTIDE, Roger (2001). O Candomblé da Bahia: rito nagô. Tradução de Maria Isaura Pereira de Queiroz. São Paulo: Companhia das Letras.

BORNHEIM, Gerd (1992). O expressionismo. In: BORNHEIM, Gerd. Brecht: a estética do teatro. Rio de Janeiro: Graal. p. 23-41.

CABRERA, Lydia (2004). Iemanjá e Oxum: iniciações, ialorixás e olorixás. Tradução de Carlos Eugênio Marcondes de Moura. São Paulo: Edusp.

DANTAS, Beatriz Góis (1988). Vovô nagô e papai branco: usos e abusos da África no Brasil. Rio de Janeiro: Graal.

LUNA, Sandra (2008). A tragédia no teatro do tempo: das origens clássicas ao drama moderno. João Pessoa: Ideia.

LUZ, Marco Aurélio (2000). Agadá: dinâmica da civilização africano-brasileira. Salvador: Edufba.

MARTINS, Leda Maria (1995). A cena em sombras. São Paulo: Perspectiva.

NASCIMENTO, Abdias do (1961). Dramas para negros e prólogo para brancos. Rio de Janeiro: Teatro Experimental do Negro.

NASCIMENTO, Abdias do (1978). O genocídio do negro brasileiro: processo de um racismo mascarado. Rio de Janeiro: Paz e Terra.

NASCIMENTO, Abdias do (1979). Sortilégio II: mistério negro de Zumbi redivivo. Rio de Janeiro: Paz e Terra.

NASCIMENTO, Abdias do (2004). Teatro Experimental do Negro: trajetória e reflexões. Estudos Avançados, São Paulo, v. 18, n. 50, p. 209-224, jan./abr.

PRANDI, Reginaldo (1996). Herdeiras do axé: sociologia das religiões afro-brasileiras. São Paulo: Hucitec.

PRANDI, Reginaldo (2001). Mitologia dos Orixás. São Paulo: Companhia das Letras.

PRANDI, Reginaldo (2005). Segredos guardados: Orixás na alma brasileira. São Paulo: Companhia das Letras.

RISÉRIO, Antonio (1996). Oriki Orixá. São Paulo: Perspectiva.

RODRIGUES, Nelson (2010). Vestido de noiva. 3. ed. Rio de Janeiro: Nova Fronteira.

SARRAZAC, Jean-Pierre (2011). O outro diálogo: elementos para uma poética do drama moderno e contemporâneo. Tradução de Luís Varela. Évora: Licorne.

SARRAZAC, Jean-Pierre (2013). Sobre a fábula e o desvio. Tradução de Fátima Saad. Rio de Janeiro: 7 Letras: Teatro do Pequeno Gesto.

SIQUEIRA, José Jorge (2006). Entre Orfeu e Xangô. Rio de Janeiro: Pallas. 